\title{
Evaluation of Insulin Resistance During Inhibition of Endogenous Insulin and Glucagon Secretion by Somatostatin in Non-Obese Subjects with Impaired Glucose Tolerance
}

\author{
K. P. Ratzmann, W. Besch, S. Witt and B. Schulz \\ Central Institute for Diabetes "Gerhardt Katsch", Karlsburg, German Democratic Republic
}

Summary. Insulin resistance was studied in seven non-obese male subjects with impaired glucose tolerance and four healthy, age and body-weight matched male control subjects by means of a continuous intravenous infusion of somatostatin, glucose and insulin over $150 \mathrm{~min}$. Glucose tolerance was evaluated by means of a 2-h glucose infusion test. Endogenous insulin (C-peptide), growth hormone, and glucagon secretion were suppressed by somatostatin in both groups. Steady-state plasma insulin and glucose levels were achieved between 90-135 min. Since similar steady-state levels of exogenous insulin were achieved, the resulting steady-state plasma glucose level provided a direct estimate of the ability of insulin to dispose of the infused glucose. The glucose levels were higher in subjects with impaired glucose tolerance with values of $14.6 \pm 1.8 \mathrm{mmol} / 1$ compared with $5.1 \pm 1.2 \mathrm{mmol} / 1$ in control subjects $(p<0.01)$, thus indicating insulin resistance. There was a direct correlation between the steady-state plasma glucose level and glucose tolerance suggesting that the degree of glucose intolerance is proportional to the degree of insulin resistance. These results revealed that decreased insulin sensitivity is found in non-obese subjects with impaired glucose tolerance.

Key words: Insulin resistance, somatostatin infusion, C-peptide, insulin, pancreatic glucagon, growth hormone, non-esterified fatty acids, impaired glucose tolerance.

Abnormalities in carbohydrate metabolism can result from either decreased insulin secretion or increased resistance in insulin responsive tissues or both. Insulin resistance is well established in Type 2 (insulin independent) diabetes and in patients with impaired glucose tolerance $[10,11,14,22]$. To determine the degree of insulin resistance, Shen et al. [25] have described an infusion technique in which patients receive a constant intravenous infusion of adrenaline, propranolol, glucose and insulin. Under these experimental conditions endogenous insulin secretion is inhibited and the height of the steady-state plasma glucose concentration is considered as a direct measure of the ability of identical amounts of exogenous insulin to promote disposition of the infused glucose load $[10,11,22,25]$. However, adrenaline and propranolol exert direct effects on carbohydrate and lipid metabolism, and may interfere with the ability of insulin to stimulate glucose disposal and to influence lipolysis.

Somatostatin inhibits both insulin and glucagon release from the pancreas [9] without any direct effect on glucose uptake [3]. Given these properties, somatostatin can be regarded as an appropriate tool to study insulin sensitivity in vivo $[12,18]$. Harano et al. [12] and Nagulesparan et al. [18] used somatostatin to assess the insulin resistance in vivo in diabetic patients and obese subjects with normal glucose tolerance. The present study was carried out to determine the degree of insulin resistance by means of a continuous infusion of somatostatin, glucose and insulin in non-obese subjects with impaired glucose tolerance.

\section{Subjects and Methods}

Seven non-obese male subjects with normal fasting plasma glucose concentration but with impaired glucose tolerance and four healthy age and weight matched male controls were studied (Table 1). Informed consent was obtained from all subjects after fully explaining the nature, purpose, and possible side effects involved in the study. The subjects did not suffer from any other disease as 
Table 1. Clinical and metabolic characteristics of subjects classified as having normal or impaired glucose tolerance (mean \pm SEM)

Criteria of the glucose infusion test

\begin{tabular}{|c|c|c|c|c|c|c|c|c|c|}
\hline & & & & & & & & & \\
\hline & & & & & & Plasma gluco & & Plasma insuli & RI) \\
\hline & $\begin{array}{l}\text { No. } \\
\text { of } \\
\text { Sub- } \\
\text { jects }\end{array}$ & $\begin{array}{l}\text { Body } \\
\text { weight } \\
(\mathrm{kg})\end{array}$ & $\begin{array}{l}\text { Relative } \\
\text { body } \\
\text { weight } \\
(\%)\end{array}$ & $\begin{array}{l}\text { Age } \\
\text { (years) }\end{array}$ & $\begin{array}{l}\text { Fasting } \\
\text { plasma } \\
\text { glucose con- } \\
\text { centration } \\
(\mathrm{mmol} / \mathrm{l})\end{array}$ & $\begin{array}{l}\text { Area-plasma } \\
\text { glucose } \\
60-120 \mathrm{~min} \\
\left(\mathrm{mmol} \cdot 1^{-1}\right. \\
\left.\min ^{-1}\right)\end{array}$ & $\begin{array}{l}\text { Plasma } \\
\text { glucose- } \\
150 \mathrm{~min} \\
(\mathrm{mmol} / 1)\end{array}$ & $\begin{array}{l}\triangle I R I \text {-area } \\
0-5 \text { min } \\
\left(\mathrm{nmol} \cdot 1^{-1} .\right. \\
\left.\min ^{-1}\right)\end{array}$ & $\begin{array}{l}\Delta \mathrm{IRI} \text {-area } \\
30-120 \text { min } \\
\left(\mathrm{nmol} \cdot 1^{-1}\right. \\
\left.\min ^{-1}\right)\end{array}$ \\
\hline $\begin{array}{l}\text { Healthy } \\
\text { controls }\end{array}$ & 4 & $72 \pm 4$ & $100 \pm 5$ & $37 \pm 1$ & $3.8 \pm 0.3$ & $552 \pm 47$ & $3.1 \pm 0.2$ & $0.6 \pm 0.2$ & $23 \pm 3$ \\
\hline $\begin{array}{l}\text { Impaired } \\
\text { glucose } \\
\text { tolerance }\end{array}$ & 7 & $73 \pm 2$ & $104 \pm 3$ & $41 \pm 4$ & $4.1 \pm 0.5$ & $\begin{array}{l}1249 \pm 68 \\
p<0.05\end{array}$ & $\begin{array}{l}13.4 \pm 1.6 \\
p<0.01\end{array}$ & $0.2 \pm 0.2$ & $24 \pm 6$ \\
\hline
\end{tabular}

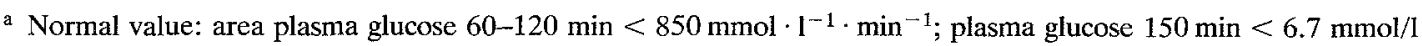

determined by physical examination and routine laboratory studies. None was under treatment with drugs. All studies were performed after a diet $(50 \%$ carbohydrate, $30 \%$ fat and $20 \%$ protein) including $250 \mathrm{~g}$ of carbohydrate for the 3 days before the study with the subject at complete bed rest following an overnight fast. Table 1 shows some of the clinical characteristics as well as estimates of glucose tolerance and insulin response in the two groups. The relative body weight was estimated according to the tables of Möhr and Johnson [17]. Glucose tolerance and insulin response patterns were characterized by means of a glucose infusion test consisting of an initial injection of $0.33 \mathrm{~g}$ glucose $/ \mathrm{kg}$ body weight followed by $12 \mathrm{mg} / \mathrm{kg}$ body weight $/ \mathrm{min}$ for $2 \mathrm{~h}$.

The criteria for the evaluation of glucose tolerance were derived on the basis of discriminant analysis from the results obtained in $\mathbf{1 1 5}$ healthy normal weight subjects without a family history of diabetes [16]. Glucose tolerance was estimated by determining the area of plasma glucose below the glucose curve at 60-120 min (normal value $<850 \mathrm{mmol} / \mathrm{1}^{-1} \mathrm{~min}^{-1}$ ) and the plasma glucose concentration at $150 \mathrm{~min}$ (normal value < $6.7 \mathrm{mmol} / 1$ ). The acute and late phases of insulin (IRI) response were expressed as incremental IRI-area above $0 \mathrm{~min}$ level from 0-5 min ( $\triangle I R I$-area $0-5 \mathrm{~min}$ ) and from 30-120 min ( $\triangle \mathrm{IRI}$-area $30-120 \mathrm{~min}$ ), respectively.

Three days after a glucose infusion test, a modification of the procedure of Shen et al. [25] was used for studying insulin resistance. After the same dietary preparation and following a 12-h overnight fast, an indwelling teflon cannula was inserted into an anticubital vein. All subjects received an IV injection of $125 \mu \mathrm{g}$ cyclic somatostatin (Serono, Freiburg, FRG) within 5 min followed by a combined constant infusion of $250 \mu \mathrm{g} / \mathrm{h}$ somatostatin, $12 \mathrm{mg} \mathrm{kg}^{-1} \mathrm{~min}^{-1}$ glucose and $1 \mathrm{mU} \mathrm{kg}^{-1} \mathrm{~min}^{-1}$ Actrapid insulin (Novo Industrias, Copenhagen, Denmark) for $150 \mathrm{~min}$. Blood samples were drawn at $-30,-5,0,5,15,30,60,90,105,120$, 135,150 and $180 \mathrm{~min}$ for the determination of plasma glucose (Beckman analyzer), non-esterified fatty acid (NEFA) [7], glycerol [8], growth hormone [15] and plasma IRI concentrations [26].

The coefficient of variation of the insulin radioimmunoassay was $6.1 \%$. Pancreatic glucagon was measured by radioimmunoassay using specific antiserum R 4 obtained from a rabbit by immunization with cross-linked glucagon [27]. This antiserum R 4 did not cross-react with porcine gut-glucagon-like immunoreactivity in a physiological range. The coefficient of variation in the concentration range of $17-25 \mathrm{pmol} / 1$ of glucagon for any plasma sample was found to be $15 \%$. C-peptide was measured after the removal of pro-insulin and following on alcoholic extraction. In order to bind the proinsulin, which cross-reacts with the C-peptide antiserum, $0.5 \mathrm{ml}$ of plasma was incubated with guinea-pig anti-insulin serum for $4 \mathrm{~h}$. After alcoholic precipitation C-peptide immunoreactivity remained in the supernatant and the aqueous phase was frozen out following the addition of ether. Samples were lyophilized and dissolved with $0.1 \mathrm{ml}$ glycine buffer $(0.05 \mathrm{~mol} / 1, \mathrm{pH} 8.6)$ containing $3 \mathrm{~g} / \mathrm{l}$ human albumin and assayed for C-peptide immunoreactivity by the back titration method using alcohol as a separating agent. The recovery of $\mathrm{C}$-peptide from plasma was found to be $77.5 \pm$ $1.7 \%$ (mean $\pm \mathrm{SEM} ; n=20)$.

Results are presented as mean \pm SEM. Student's t-test for paired or unpaired data defined the significance of difference between the means within a group or between groups.

\section{Results}

Mean plasma glucose and insulin concentrations of controls and subjects with impaired glucose tolerance during the glucose infusion test are presented in Fig. 1. The fasting plasma glucose values were comparable in both groups, whereas the glucose response was more than twice in subjects with impaired glucose tolerance compared with normal subjects (Table 1). The insulin response in subjects with impaired glucose tolerance was characterized by a reduced initial insulin secretion phase, whereas the plasma insulin concentration after termination of the glucose infusion was significantly higher in comparison with controls (Fig. 1 and Table 1).

Mean basal plasma C-peptide levels before the somatostatin infusion were not significantly different between controls and patients with impaired glucose tolerance (Fig. 2). Endogenous insulin secretion was inhibited during the combined infusion of somatostatin, glucose and insulin in both groups, as indicated by suppression of C-peptide levels (Fig. 2). Mean basal plasma C-peptide levels decreased from $0.46 \pm$ 0.11 to a minimum of $0.10 \pm 0.07 \mathrm{nmol} / 1$ in controls 

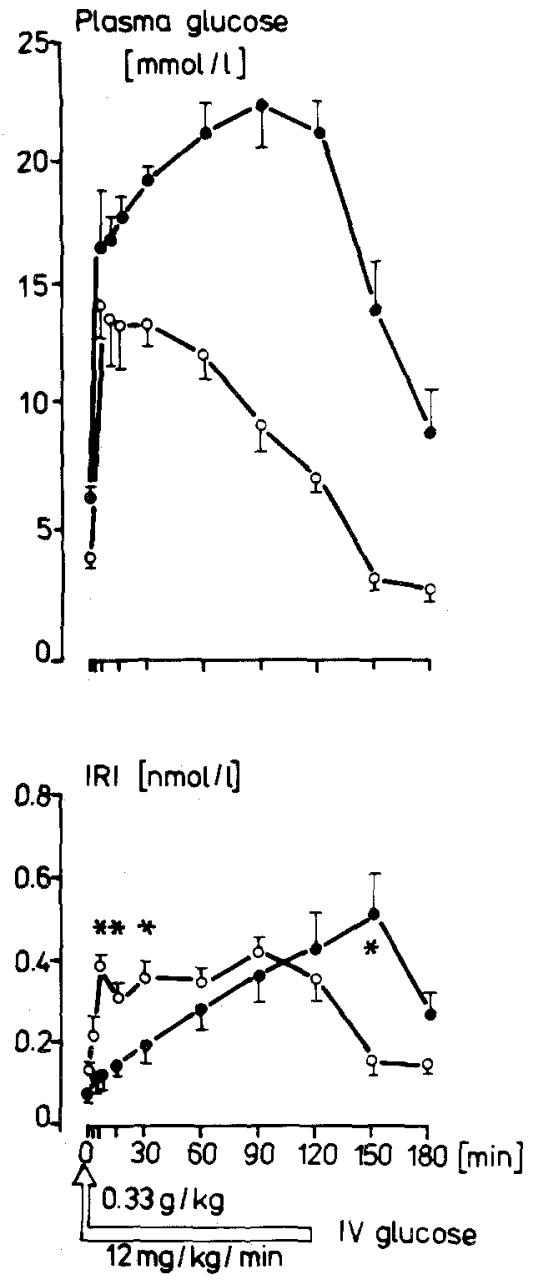

Fig. 1. Plasma glucose and plasma insulin responses (mean \pm SEM) during a glucose infusion test in healthy controls $(\mathrm{O}-\mathrm{O}$, $n=4)$ and subjects with impaired glucose tolerance $n=7) . * p<0.05$

(NS) and from $0.40 \pm 0.08$ to $0.16 \pm 0.06 \mathrm{nmol} / 1$ $(p<0.05)$ in subjects with impaired glucose tolerance. Pancreatic glucagon concentrations were also suppressed during the infusion of somatostatin, glucose and insulin in the two groups (Fig. 3). Mean basal pancreatic glucagon concentration decreased from $22 \pm 6$ to a minimum of $11 \pm 3 \mathrm{pmol} / 1$ in controls $(p<0.05)$ and from $37 \pm 5$ to $7 \pm 1 \mathrm{pmol} / 1$ in subjects with impaired glucose tolerance $(p<0.01$; Fig. 3). Pancreatic glucagon levels remained parallel during the infusion and were not significantly different in the two groups. A slight increase of pancreatic glucagon was noted after termination of the infusion in both groups (Fig. 3). Plasma growth hormone
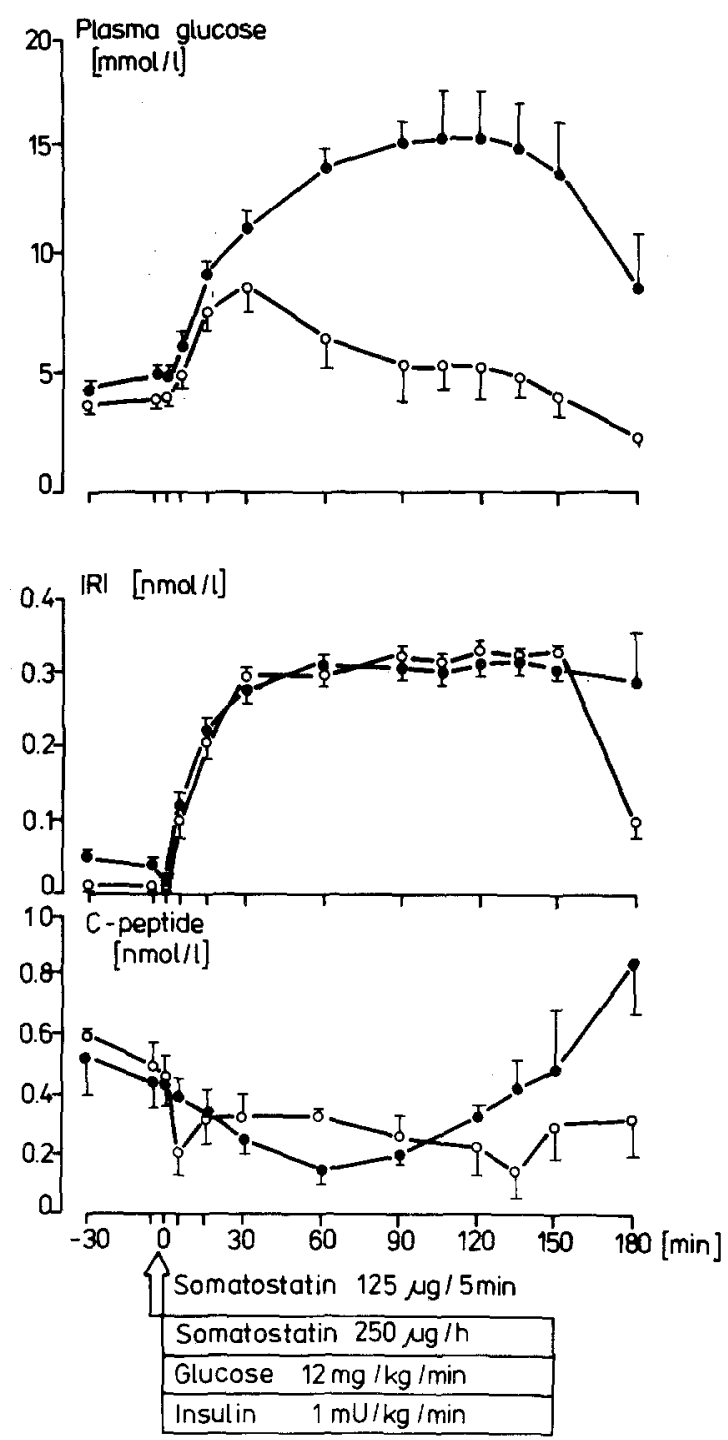

Fig. 2. Plasma glucose, plasma insulin, and C-peptide levels (mean \pm SEM) of healthy controls $(\mathrm{O}-\mathrm{O})$ and subjects with impaired glucose tolerance (-) during a combined infusion of somatostatin, glucose and insulin of $150 \mathrm{~min}$

levels were also suppressed in controls and subjects with impaired glucose tolerance to a minimum of $0.03 \pm 0.01$ and $0.01 \pm 0.01 \mathrm{nmol} / 1$ respectively (Fig. 3).

During the combined infusion of somatostatin, glucose and insulin, plasma insulin levels increased in a similar manner in controls and subjects with impaired glucose tolerance (Fig. 2). Steady-state plasma insulin concentration was reached after $90 \mathrm{~min}$ in the two groups. The mean steady-state plasma insulin concentration during the time interval 90-135 min was closely similar in controls and subjects with impaired glucose tolerance $(0.34 \pm 0.03$ versus $0.33 \pm 0.04 \mathrm{nmol} / 1$ ) In contrast, Fig. 2 demon- 
strates clear differences of the groups regarding plasma glucose response to an infusion of somatostatin, glucose and insulin. Steady-state plasma glucose levels were reached after $90 \mathrm{~min}$ and remained constant until $135 \mathrm{~min}$. The mean steady-state plasma glucose levels were significantly higher in subjects
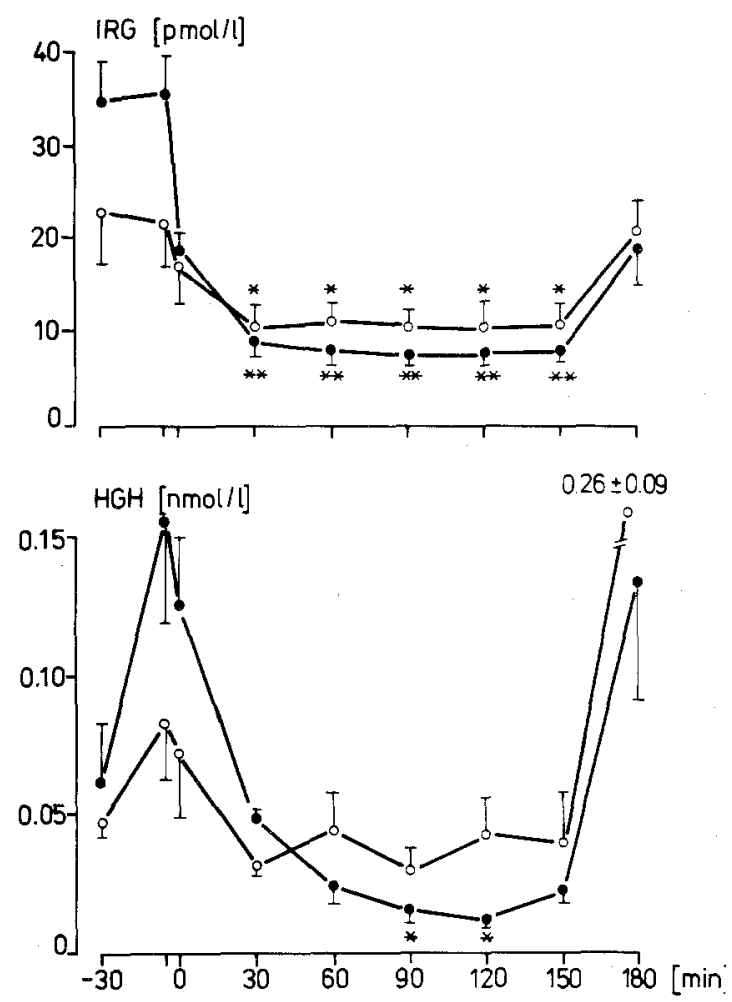

Fig. 3. Pancreatic glucagon (IRG) and growth hormone responses $(\mathrm{HGH})$ (mean \pm SEM) in healthy controls $(\mathrm{O}-\mathrm{O}$ ) and subjects with impaired glucose tolerance (-@) during a combined infusion of somatostatin, glucose and insulin of $150 \mathrm{~min}$. * $p<0.05$, $* p<0.01$ versus values before the combined infusion with impaired glucose tolerance compared with controls $(14.6 \pm 1.8$ versus $5.1 \pm 1.2 \mathrm{mmol} / 1 ; p<0.01)$. There was a direct correlation between the steadystate plasma glucose and estimates of glucose tolerance for the two groups combined (Fig. 4). This relationship was not found when the two groups were analyzed separately. There was no relationship between steady-state plasma glucose levels and estimates of insulin secretion (fasting IRI-level, $\triangle \mathrm{IRI}$ area $0-5 \mathrm{~min}, \Delta \mathrm{IRI}$-area $30-120 \mathrm{~min}$ ), fasting pancreatic glucagon, or fasting growth hormone levels.

Mean plasma NEFA and glycerol concentrations decreased in response to the infusion of somatostatin, glucose and insulin in both groups (Fig. 5). Plasma NEFA levels were significantly higher in subjects with impaired glucose tolerance compared with the control subjects at 15,30 and $60 \mathrm{~min}$, whereas no differences were apparent from 90 to $135 \mathrm{~min}$. Both the absolute and the relative decrease in plasma NEFA and glycerol concentration were comparable in both groups of subjects. The steady-state plasma glucose was not correlated with either the absolute or the relative decrease in NEFA or glycerol concentrations.

\section{Discussion}

Our results confirm previous studies that patients with mild decreases of carbohydrate tolerance respond to an IV glucose load with significant hyperinsulinaemia after termination of glucose infusion [24]. Apart from disturbances of insulin secretion, insulin resistance is well documented by several studies $[10,11,20,22]$. Insulin resistance was previously determined by a method involving a continuous IV infusion of adrenaline, propranolol, glucose and insulin. Under these experimental conditions

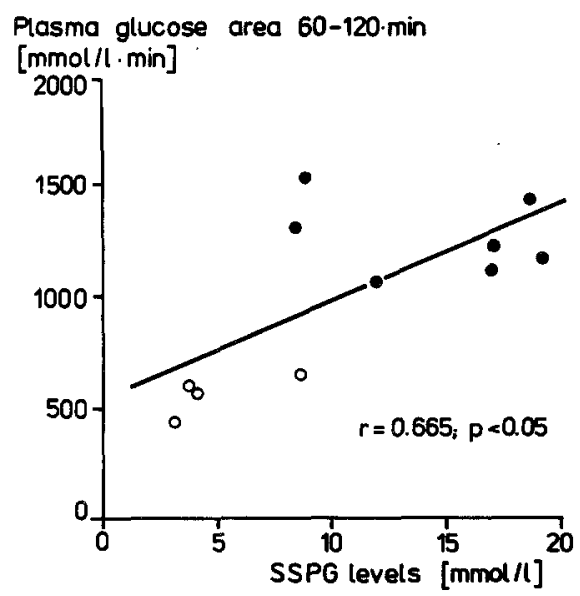

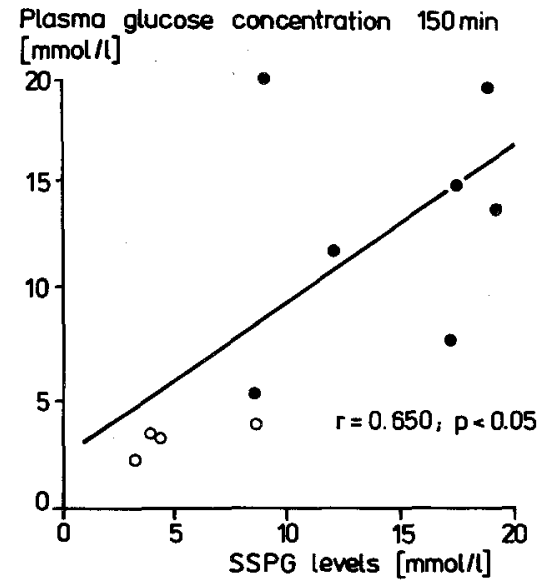

Fig. 4. The relationship between estimates of glucose tolerance (plasma glucose area 60-120 min and plasma glucose concentration at $150 \mathrm{~min}$ ) and steady-state plasma glucose levels (SSPG) in all subjects studied ( $\bigcirc$ controls, subjects with impaired glucose tolerance) 

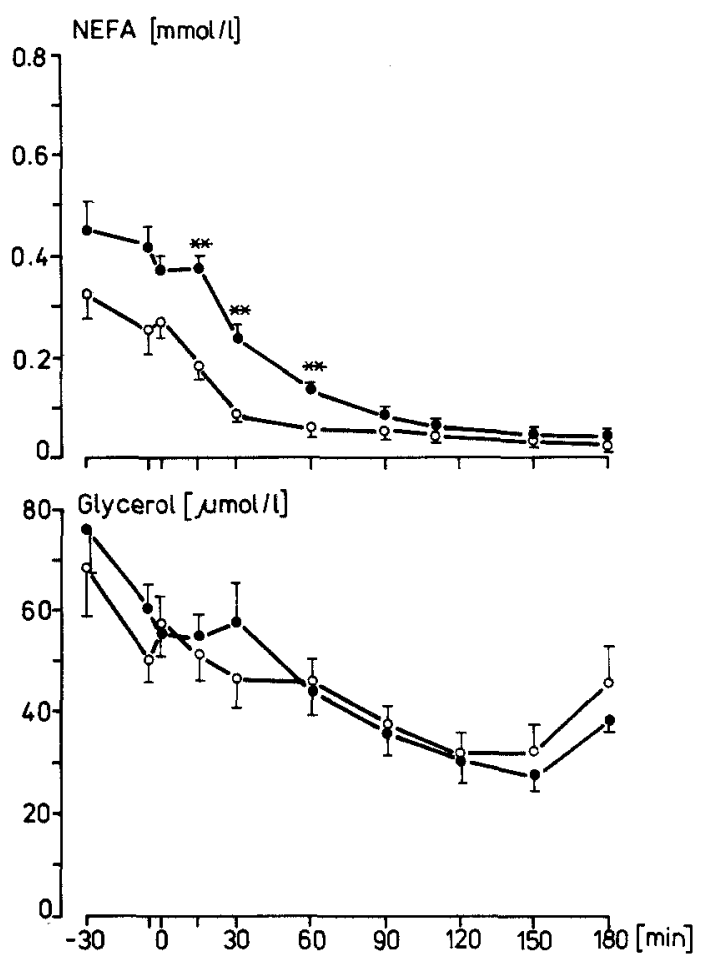

Fig. 5. Plasma NEFA and glycerol responses (mean \pm SEM) in healthy controls $(\mathrm{O}-\mathrm{O})$ and subjects with impaired glucose tolerance (-) during a combined infusion of somatostatin, glucose and insulin. $* p<0.01$

endogenous insulin secretion was inhibited and steady-state plasma glucose and exogenous insulin levels were reached after $90 \mathrm{~min}$ [25]. Bernstein et al. [2] have pointed out, however, that adrenaline and propranolol could interfere with the ability of insulin to stimulate glucose disposal and/or inhibit hepatic glucose production. Adrenaline increases glucose production, decreases glucose clearance [23], and impairs tissue sensitivity to insulin in man [5]. Propranolol had no effect on insulin mediated glucose metabolism [5]. Thus different pharmacological effects in patients with diabetes could account for the fact that these patients have higher steady-state plasma glucose concentrations. Another technique to measure insulin resistance is the euglycaemic and hyperglycaemic clamp technique [6]. The procedure is complicated and, if hyperglycaemia is produced, endogenous insulin release is stimulated. For this reason somatostatin has recently been used to suppress endogenous insulin release, and thereby it becomes possible to investigate the efficiency of exogenous insulin on glucose metabolism in vivo [12, 18]. Somatostatin also has the advantage of having no direct effect on basal or insulin stimulated glucose uptake of skeletal muscle, or on hepatic glucose production $[3,9]$.
The results of the present study indicate that the mean steady-state plasma glucose was significantly higher in subjects with impaired glucose tolerance than in controls demonstrating the existence of insulin resistance in the former group. In contrast to this observation the decrease in plasma NEFA and glycerol was comparable in the two groups suggesting no reduced insulin sensitivity of adipose tissue lipolysis in subjects with impaired glucose tolerance. This is in agreement with findings of Howard et al. [13] who have demonstrated marked sensitivity to the antilipolytic effect of insulin in obese Type 2 (insulin independent) diabetics considered to be resistant to its glucose lowering action. However, the effect of varying doses of insulin was not studied in the present study so that dose-response curves could not be obtained. For this reason insensitivity to insulin can be missed if the studies were carried out on the maximal part of the insulin dose-response curve.

Theoretically, higher steady-state plasma glucose levels in subjects with impaired glucose tolerance could be due to the presence of circulating insulin antagonists or to direct tissue resistance to the action of insulin. Growth hormone and glucagon are well recognised insulin antagonists but they were decreased to a comparable level in both groups of subjects studied. In addition, elevated NEFA concentrations in subjects with impaired glucose tolerance might contribute to insulin resistance [1] and glucose intolerance [21]. However, we found plasma NEFA concentrations to be suppressed to the same level both in controls and subjects with impaired glucose tolerance.

Olefsky and Reaven $[19,20]$ have demonstrated a reduced number of insulin receptors in "chemical" and non-ketotic diabetics and the decreased insulin binding in these subjects was inversely correlated with the degree of insulin resistance. Moreover, abnormalities in intracellular glucose metabolism might also contribute to insulin resistance observed in patients with mild diabetes [4].

In conclusion, our results demonstrate that insulin resistance exists in non-obese patients with impaired glucose tolerance and add further support to the view that the degree of glucose intolerance in these patients is proportional to their degree of insulin resistance [10]. Furthermore, the validity of these conclusions has been confirmed by the use of a technique $[12,18]$ which avoids the effects of adrenaline and propranolol on glucose metabolism.

Acknowledgements. The authors are grateful to Dr. G. M. Reaven, Veterans Administration Hospital, Palo Alto, California, USA, for his valuable comments and his generous help in reviewing the manuscript. Anti-serum to $\mathrm{C}$-peptide and tyrosilated C-peptide were gifts from Dr. A. H. Rubinstein (Chicago). 
Investigations have been carried out in the medical research project "Diabetes mellitus and distrubances of lipid metabolism" supported by the Ministry of Health, GDR. Presented in part at the 14th Annual Meeting of the European Society for Clinical Investigation, April 24-26 (1980) in Salzburg.

\section{References}

1. Balasse E, Neef MA (1974) Operation of the "glucose-fattyacid-cycle" during experimental elevation of plasma free fatty acid levels in man. Eur J Clin Invest 4: 247-252

2. Bernstein RM; Davis BM, Olefsky JM, Reaven GM (1978) Hepatic insulin responsiveness in patients with endogenous hypertriglyceridaemia. Diabetologia 14: 249-253

3. Cherrington AD, Caldwell MD, Dietz MR, Exton JH, Crofford OG (1977) The effect of somatostatin on glucose uptake and production by rat tissues in vitro. Diabetes 26: 740-748

4. Czech MP, Richardson DK, Smith CJ (1977) Biochemical basis of fat cell insulin resistance in obese rodents and man. Metabolism 26: 1057-1078

5. Deibert DC, DeFronzo RA (1980) Epinephrine-induced insulin resistance in man. J Clin Invest 65: 717-721

6. DeFronzo PA (1979) Glucose intolerance and aging. Evidence for tissue insensitivity to insulin. Diabetes 28: 1095-1101

7. Duncombe WC (1964) The colorimetric micro-determination of non-esterified fatty acids in plasma. Clin Chim Acta 9: 122-125

8. Eggstein M, Kreutz FH (1966) Eine neue Bestimmung der Neutralfette im Blutserum und Geweben, Prinzip, Durchführung und Besprechung der Methode. Klin Wochenschr 44: 262-267

9. Gerich JE, Lorenzi M, Scheider V, Karam JH, Rivier J, Guellemin R, Forsham PH (1974) Effects of somatostatin on plasma glucose and glucagon levels in human diabetes mellitus. N Engl J Med 29: 544-547

10. Ginsberg H, Olefsky JO, Reaven GM (1974) Further evidence that insulin resistance exists in patients with chemical diabetes. Diabetes 23: 674-678

11. Ginsberg H, Kimmerling G, Olefsky JM, Reaven GM (1975) Demonstration of insulin resistance in untreated adult onset diabetic subjects with fasting hyperglycemia. J Clin Invest 55: 454-461

12. Harano $Y$, Ohgaku S, Hidake $H$, Haneda $K$, Kikkawa $R$, Shigeta Y, Abe H (1977) Glucose, insulin and somatostatin infusion for the determination of insulin sensitivity in vivo. $\mathrm{J}$ Clin Endocrinol Metab 45: 1124-1127

13. Howard BV, Savage PJ, Nagulesparan M, Bennion LJ, Unger RH, Benett PH (1979) Evidence for marked sensitivity to antilipolytic action of insulin in obese maturity-onset diabetics. Metabolism 28: 744-750

14. Kimmerling G, Javorski WC, Olefsky JM, Reaven GM (1976) Locating the site(s) of insulin resistance in patients with nonketotic diabetes mellitus. Diabetes 25: 673-678

15. Lambert AK, Layekes Y, Zahnd GR (1967) Improvement of human growth hormone immunoassay using ${ }^{125}$ I. Proc Soc Exp Biol Med 126: 405-409

16. Michaelis D, Schulz B, Neumann I, Wulfert P, Ziegler M, Wüstenberg PW, Kunkel S, Werner P, Lohmann L, Verlohren HJ (1975) Diagnostik der Vorstadien des Diabetas mellitus. 2. Mitteilung: Normwerte und Beurteilungskriterien des Glukoseinfusionstest (GIT). Dtsch Gesundheitswes 30: 1359-1366

17. Möhr M, Johnson D (1972) Tabellen zur Beurteilung des Körpergewichtes erwachsener Männer und Frauen nach deren Optimalgewicht. Z Ärztl Fortbild 66: 1052-1064

18. Nagulesparan M, Savage PJ, Unger RH, Bennett PH (1979) A simplified method using somatostatin to assess in vivo insulin resistance over a range of obesity. Diabetes 28: 980-983

19. Olefsky JM, Reaven GM (1974) Decreased insulin binding to lymphocytes from diabetic subjects. J Clin Invest 54: 1323-1328

20. Olefsky JM, Reaven GM (1977) Insulin binding in diabetes Relationship with plasma insulin levels and insulin sensitivity. Diabetes 26: 680-688

21. Ratzmann KP, Michaelis D, Honigmann G (1975) Die Erhöhung der Aussagekraft des intravenösen Glukosetoleranztest durch Mitbestimmung der freien Fettsäuren. Dtsch Gesundheitswes 30: 1070-1076

22. Reaven GM, Olefsky JM (1977) Relationship between heterogeneity of insulin responses and insulin resistance in normal subjects and patients with chemical diabetes. Diabetologia 13: 201-206

23. Rizza RA, Cryer PE, Haymond HW, Gerich JE (1980) Adrenergic mechanism for the effects of epinephrine on glucose production and clearance in man. J Clin Invest 65: 682-689

24. Schulz B, Knospe S, Hildmann W, Ratzmann KP (1979) Insulin sensitivity of non-obese asymptomatic diabetics in vivo in relation to insulin responsiveness of their adipose tissue in vitro. Diabete Metab 5: 269-273

25. Shen SW, Reaven GM, Farquhar JW, Nakanishi RH (1970) Comparison of impedance to insulin mediated glucose uptake in normal subjects and in subject with latent diabetes. J Clin Invest 49: 2151-2160

26. Ziegler M, Karg K, Gens J, Johannsen B, Michael R, Michaelis D (1971) Anwendung des Radioimmunbestecks "Insulin" bei Insulinsekretionsstudien. In: VIII. Symposium Sektion Nuklearmedizin der Gesellschaft für medizinische Radiologie, Reinhardsbrunn. Schwarz KD, Berlin, pp 141-146

27. Ziegler M, Hahn HJ, Ziegler B, Böttcher E, Fiedler H (1975) Paradoxical glucagon response after stimulation with glucose and arginine in isolated pancreatic sand rat islets. Diabetologia 11: 63

Received: 11 March 1980

and in revised form: 9 April 1981

Dr. sc. med. K. P. Ratzmann

Zentralinstitut für Diabetes "Gerhardt Katsch"

DDR-2201 Karlsburg, German Democratic Republic 